\title{
Screening of Chickpea Germplasm / Genotypes against Fusarium Wilt of Chickpea under Field and Artificial Condition
}

\author{
K. Venkataramanamma ${ }^{1 *}$, B.V. Bhaskara Reddy ${ }^{2}$, R. Sarada Jayalakshmi ${ }^{3}$, \\ V. Jayalakshmi ${ }^{4}$, K.V. Hari Prasad ${ }^{5}$ and G. Mohan Naidu ${ }^{6}$ \\ ${ }^{1}$ Department of Pl. Path, ${ }^{4}$ Department of Plant Breeding, RARS, Nandyal, \\ ANGRAU, A.P., India \\ ${ }^{2}$ Department of Plant Path, RARS, Tirupati, A.P., India \\ ${ }^{3}$ Department of Pl. Pathology, ${ }^{5}$ Department of Entomology, ${ }^{6}$ Department of Statistics, S.V. \\ Agriculture College, Tirupati, A.P., India \\ *Corresponding author
}

\section{A B S T R A C T}

\section{Keywords}

Chickpea, Screening,

Fuarium wilt, Sick

plot and green house

Article Info

Accepted:

08 August 2018

Available Online:

10 September 2018
Fusarium wilt caused by Fusarium oxysporum f.sp. ciceris is one of the major disease causes upto $90 \%$ losses depending on weather conditions. Eighty five germplasm/genotypes of chickpea were screened at wilt sick plot existing at RARS, Nandyal for two rabi seasons i.e., 2014-15 and 2015-16. Based on the results obtained in two years, 13 entries representing 7 resistant (ICC-294, ICC-6279, ICC-14669, NBeG-3, NBeG-47, NBeG-119 and NBeG-49) and 6 moderately resistant (ICC-1398, NBeG-119, ICC-67, NBeG-458, NBeG-47 and NBeG-452) varieties/ germplasm were selected for green house screening for three virulent $F$. oxysporum f.sp. ciceris isolates such as Foc-6, Foc-12 and Foc-17 for confirmation of field screening results. Under artificial screening five entries such as NBeG-3, ICC-14669, NBeG-49, ICC-6279 and ICC-294 were recorded $0 \%$ incidence for all the three virulent $F$. oxysporum f.sp. ciceris isolates.

\section{Introduction}

Chickpea (Cicer arietinum L.) is an important pulse crop of India. This grain legume is cultivated in over 50 countries in the world and infested by more than 52 number of pathogens (Nene et al., 1984). Among the diseases, Fusarium wilt caused by Fusarium oxysporum f.sp. ciceris (Padwick) Matuo and Sato (FOC) is highly destructive and worldwide in occurrence (Nene et al., 1989). The disease can occur at all the stages of plant growth from seedling to maturity and causes an annual yield loss of 10-90\% (Jiminez-Diaz et al., 1989). The incidence is more if the crop is subjected to sudden temperature rise and water stress. The fungus enters the vascular tissues of plant via roots. At seedling stage, disease symptoms appear three weeks after sowing. They exhibit drooping and pale coloured leaves and finally collapsed. The affected adult plants showed typical wilt symptoms of drooping of petioles, rachis and leaflets. When uprooted they showed uneven 
shrinking of stem below the collar region. The roots of the wilting plants did not show any external rotting, but dark brown discoloration of internal xylem was seen. More yield losses occurred due to early wilting than late wilting. It is a seed borne pathogen. Due to the dynamic nature of this soil borne pathogen, it can be effectively controlled by the exploration of host plant resistance (Jalali and Chand, 1992). Since most of the commercial cultivars in the country have been found susceptible, and extensive screening of germplasm for the identification of resistant sources is required. Development and use of high yielding cultivars resistant to the prevalent pathogen race(s) in a given area is the most practical and cost efficient individual disease control measure for management of the disease.

\section{Materials and Methods}

Eighty five lines representing fifty four germ plasm lines (mini core collection) and thirty one advanced genotypes developed by AICRP on Chickpea scheme operated at RARS, Nandyal were screened in wilt sick plot for two rabi seasons i.e., 2014-15 and 2015-16. The experiment was conducted in randomized block design in two replications. Each germplasm line was sown in $3 \mathrm{~m}$ in a single row with $30 \times 10 \mathrm{~cm}$ spacing. A susceptible check, JG-62 was sown after every two test rows in the whole field. These rows served as checks and will help in monitoring and maintaining the wilt sickness of the plot. For every 10 rows resistant check WR-315 was sown for comparing the level of resistance in these lines. The experiment was conducted by following general agronomic practices. Sowing was done in the month of October and harvesting was done in the month of February. Data on disease incidence was recorded periodically at 30,60 and 90 days after sowing and final wilt incidence was calculated for all the genotypes screened.
Wilt incidence

$\frac{\text { Number of wilted plants }}{\text { Total number of plants }} \times 100$

The level of resistance and/or susceptibility for each line was determined by using 1-9 rating scale (Anonymous, 2014).

Local severity index (LSI) was calculated for sickness in wilt sick plot and it indicates severity of the disease at a location. It was calculated by using the below formula.

\section{LSI}

Total per cent wilt incidence of

$$
\frac{\text { set of entries in a given location }}{\text { Total number of entries }} \times 100
$$

\section{Artificial screening}

The entries which were identified as resistant and moderately resistant during natural screening in wilt sick plot were subjected to artificial screening by following root dip inoculation technique given by Pande et al., (2006). These entries were screened for three virulent Fusarium oxysporum f.sp. ciceris isolates such as Foc-6, Foc-12 and Foc-17 representing three districts such as Kurnool, Prakasam and Anantapuramu districts of Andhra Pradesh respectively. Three $F$. oxysporum f.sp. ciceris isolates exhibited $100 \%$ wilting on susceptible check JG-62 during pathogenicity test. Susceptible cultivar JG-62 along with the selected 13 germplasm/genotypes were raised in polythene bags filled with sterilised river sand in a greenhouse maintained at $25 \pm 1{ }^{\circ} \mathrm{C}$ for eight days. For artificial screening, inoculum was prepared by inoculating a $7 \mathrm{~mm}$ disc of actively growing $F$. oxysporum f. sp. ciceris culture in $250 \mathrm{ml}$ conical flask containing 100 $\mathrm{ml}$ of sterilized potato dextrose broth. The flasks were incubated for seven days at $25 \pm$ $1^{\circ} \mathrm{C}$ in an incubator shaker with continuous 
shaking (125 rpm). The flask containing inoculum was diluted with sterile water to obtain $6 \times 10^{5}$ conidia $\mathrm{ml}^{-1}$ with the help of a haemocytometer. Eight day old seedlings of each germplasm line or genotype as well as susceptible line grown in sterilized river sand were uprooted, cleaned with tap water and root inoculated by dipping in inoculum suspension for 1-2 minutes to enable the conidia to adhere to the roots. Then such inoculated seedlings were transplanted in pots containing sterile soil and sand in 3:1 ratio and kept in a greenhouse at $25 \pm 3^{\circ} \mathrm{C}$. Thirty seedlings of each germplasm line or genotype were tested in three replications. Inoculated seedlings were observed for wilt symptoms upto 60 days and the experiment was repeated once. Data on disease incidence (per cent plant mortality) was recorded using the following formula:

Disease incidence
$\frac{\text { Number of wilted plants }}{\text { Total number of plants }} \times 100$

The level of susceptibility and resistance of each test line/genotype was determined with the help of above scale.

\section{Results and Discussion}

During, rabi 2014-15 the results revealed that out of 85 entries screened, 6 entries were found resistant, 9 entries were moderately resistant, 20 entries were moderately susceptible, 32 entries were susceptible and 18 entries were highly susceptible. During rabi 2015-16, 8 entries were found resistant, 13 were moderately resistant, 28 were moderately susceptible, 26 entries were susceptible and 10 entries were highly susceptible (Table 1). Pooled data for both the years 2014-15 and 2015-16 indicated that out of 85 germplasm lines and advanced genotypes screened for Fusarium wilt, 7 entries (ICC-294, ICC-6279, ICC-14669, NBeG-3, NBeG-47, NBeG-119 and NBeG-49) were recorded as resistant, 6 entries were moderately resistant (ICC-1398, NBeG-458, ICC-67, NBeG-452, NBeG-177, JG-11) and 26 entries are moderately susceptible, 33 entries were graded as susceptible, 13 entries were highly susceptible (Table 2).

The local severity index of wilt sick plot was recorded as $36.26 \%$. The susceptible check JG-62 was completely wilted out within 18-25 days after sowing, indicating its highly susceptible nature to Fusarium wilt and recorded $98.5 \%$ of disease. It was observed that the susceptible check was completely wilted uniformly in the field indicating that uniform distribution of inoculum. Whereas resistant check i.e., WR-315 showed only $7.8 \%$ wilt incidence in the field till the time of harvesting indicating its resistance nature.

Based on field screening data in wilt sick plot for two years, seven resistant and six moderately resistant lines (totally thirteen entries) were selected for green house screening to confirm field resistance. Significant differences were observed among the entries pertaining to wilt incidence in statistical analysis (Table 3). The results indicated that out of 13 entries, five entries such as NBeG-3, ICC-14669, NBeG-49, ICC6279 and ICC-294 were recorded 0\% incidence for all the three virulent $F$. oxysporum f.sp. ciceris isolates, six entries such as ICC-1398, NBeG-119, ICC-67, NBeG-458, NBeG-47 and NBeG-452 recorded as resistant category (showing 1-10\% wilt incidence), two isolates such as NBeG177 and JG-11 were showed moderately resistant reaction to all the three isolates. Susceptible check (JG-62) was completely wilted out in this screening.

The present study results are in close confirmation with Mehmood and Khan (2016) who screened 318 chickpea genotypes in wilt 
sick plot for Fusarium wilt of chickpea for two seasons and found three lines/varieties such as 5006, k021-10 and k035-10 as highly resistant. In the present field experiment three germplasm lines (ICC-294, ICC-6279, ICC14669) and four advanced genotypes (NBeG3, NBeG-47, NBeG-49 and NBeG-119) are showing resistant reaction. Similarly Husnain et al., (2016) screened 64 advanced lines of chickpea against the wilt in sick plot and categorized them into highly resistant (7 lines), resistant (11 lines), moderately resistant (10 lines) and susceptible (36 lines).

Fifty large-seeded kabuli chickpea germplasm from ICRISAT's gene bank were evaluated and found that two accessions, ICC 14194 and ICC 17109 showed complete resistance (0\% plant mortality) to Fusarium wilt (Gaur et al., 2006).

Saabale et al., (2017) screened 59 land races and 62 elite breeding lines of chickpea against Fusarium wilt (race 2) under sick field at IIPR, Kanpur and observed that eight land races, ten kabuli genotypes, 15 desi genotypes were highly resistant and local severity index (LSI) was higher for land races $(71.7 \%)$ compared to elite breeding lines (27.8\%). In the present experiment, local severity index (LSI) was recorded as $36.26 \%$ in the wilt sick plot. Nene and Haware (1980) identified only 14 resistant varieties out of 7000 chickpea accessions screened.

Other factors favouring the development of $F$. oxysporum f.sp. ciceris are high temperature, amount of inoculum and excess soil water (Navas-Cortes et al., 2000).

In this study same temperature was observed $\left(19.3^{\circ} \mathrm{C}\right.$ to $\left.33^{\circ} \mathrm{C}\right)$ during crop growth period for both the years, hence it was assumed that the wilting in susceptible cultivars could be due to their inherent susceptibility to pathogen.
In the present study, the screening data of both the years (rabi 2014-15 and 2015-16) indicating similar disease pattern or response to Fusarium wilt except some genotypes or germplasm lines showed some variation in disease response to Fusarium. This study showed that presence of high to moderate levels of resistance in germplasm against Fusarium wilt of chickpea.

Based on field screening data in wilt sick plot for two years, seven resistant and six moderately resistant lines (totally thirteen entries) were screened artificially in green house for three virulent isolates (Foc-6, Foc12 and Foc-17). Significant differences were observed among the entries pertaining to wilt incidence. The results indicated that out of 13 entries, five entries such as NBeG-3, ICC14669, NBeG-49, ICC-6279 and ICC-294 were recorded $0 \%$ incidence for all the three virulent $F$. oxysporum f.sp. ciceris isolates, six entries such as ICC-1398, NBeG-119, ICC-67, NBeG-458, NBeG-47 and NBeG-452 recorded as resistant category, two isolates such as NBeG-177 and JG-11 were showed moderately resistant reaction to all the three isolates. Susceptible check (JG-62) was completely wilted out in this screening.

All the entries exhibited similar type of disease pattern (wilt incidence) for three virulent isolates used in this study. The present study results are supported by Pande et al., (2006) who screened 211 mini core germplasm collections in green house for multiple disease resistance (Fusarium wilt, Botrytis grey rot, Ascochyta bight and dry root rot) and observed that 21 were asymptomatic ( $0 \%$ incidence), 25 were resistant and 21 were moderately resistant to Fusarium wilt. They grouped the same two entries such as ICC6279 and ICC-14669 obtained in the present study into asymptomatic category and other two entries such as ICC-1398 and ICC-67 into resistant category. 
Table.1 Reaction of chickpea germplasm/genotypes against Fusarium oxysporum f.sp. ciceris in wilt sick plot

\begin{tabular}{|c|c|c|c|c|c|c|}
\hline \multirow[t]{2}{*}{ S. No. } & \multirow[t]{2}{*}{ Entry name } & \multicolumn{3}{|c|}{ Wilt incidence (\%) } & \multirow[t]{2}{*}{ Grade } & \multirow{2}{*}{$\begin{array}{l}\text { Disease } \\
\text { reaction }\end{array}$} \\
\hline & & 2014-15 & 2015-16 & Average & & \\
\hline 1. & ICC-4639 & 40.64 & 44.58 & 42.61 & 7 & S \\
\hline 2. & ICC-16524 & 48.30 & 50.83 & 49.56 & 7 & S \\
\hline 3. & ICC-1397 & 77.80 & 26.93 & 52.36 & 9 & HS \\
\hline 4. & ICC-14778 & 63.40 & 56.34 & 59.87 & 9 & HS \\
\hline 5. & ICC-5879 & 35.00 & 32.66 & 33.83 & 7 & $\mathrm{~S}$ \\
\hline 6. & ICC-1398 & 14.00 & 22.82 & 18.41 & 3 & MR \\
\hline 7. & ICC-67 & 11.30 & 11.17 & 11.20 & 3 & MR \\
\hline 8. & ICC-1162 & 28.56 & 30.24 & 29.40 & 5 & MS \\
\hline 9. & ICC-294 & 09.80 & 04.00 & 06.90 & 1 & $\mathrm{R}$ \\
\hline 10. & ICC-5382 & 28.65 & 27.04 & 27.84 & 5 & MS \\
\hline 11. & ICC-10945 & 31.70 & 20.69 & 26.19 & 5 & MS \\
\hline 12. & ICC-6279 & 13.30 & 03.50 & 08.40 & 1 & $\mathrm{R}$ \\
\hline 13. & ICC-12025 & 35.00 & 29.80 & 32.40 & 7 & S \\
\hline 14. & ICC-697 & 41.70 & 29.38 & 35.54 & 7 & S \\
\hline 15. & ICC-12037 & 66.70 & 54.30 & 60.50 & 9 & HS \\
\hline 16. & ICC-2942 & 50.00 & 42.80 & 46.40 & 7 & $\mathrm{~S}$ \\
\hline 17. & ICC-3512 & 65.00 & 33.33 & 49.16 & 7 & S \\
\hline 18. & ICC-5383 & 36.70 & 33.45 & 35.07 & 7 & S \\
\hline 19. & ICC-12328 & 60.00 & 49.46 & 54.73 & 9 & HS \\
\hline 20. & ICC-6816 & 73.40 & 32.70 & 53.05 & 9 & HS \\
\hline 21. & ICC-12524 & 78.30 & 87.65 & 82.97 & 9 & HS \\
\hline 22. & ICC-1194 & 73.40 & 65.32 & 69.36 & 9 & HS \\
\hline 23. & ICC-14669 & 05.00 & 05.93 & 05.46 & 1 & $\mathrm{R}$ \\
\hline 24. & ICC-3510 & 51.70 & 41.15 & 46.42 & 7 & S \\
\hline 25. & ICC-13219 & 50.00 & 27.76 & 38.88 & 7 & S \\
\hline 26. & ICC-13863 & 51.70 & 32.16 & 41.93 & 7 & S \\
\hline 27. & ICC-9755 & 48.40 & 20.06 & 34.23 & 7 & S \\
\hline 28. & ICC-14402 & 73.60 & 61.66 & 67.63 & 9 & HS \\
\hline 29. & ICC-14051 & 40.00 & 36.66 & 38.33 & 7 & $S$ \\
\hline 30. & ICC-13124 & 43.40 & 26.50 & 34.95 & 7 & S \\
\hline 31. & ICC- 867 & 73.40 & 58.56 & 65.98 & 9 & HS \\
\hline 32. & ICC-15618 & 35.00 & 38.46 & 36.73 & 7 & $\mathrm{~S}$ \\
\hline 33. & ICC-1230 & 26.70 & 28.57 & 27.63 & 5 & MS \\
\hline 34. & ICC-5845 & 40.00 & 36.61 & 38.30 & 7 & S \\
\hline 35. & ICC-4872 & 45.00 & 39.35 & 42.17 & 7 & S \\
\hline 36. & ICC-1923 & 28.40 & 69.02 & 48.71 & 7 & S \\
\hline 37. & ICC-14831 & 43.40 & 40.90 & 42.15 & 7 & S \\
\hline 38. & ICC-2580 & 73.40 & 62.00 & 67.70 & 9 & HS \\
\hline 39. & ICC-9942 & 56.70 & 24.81 & 40.75 & 7 & S \\
\hline 40. & ICC-9862 & 100.0 & 90.00 & 95.00 & 9 & HS \\
\hline 41. & ICC-9895 & 58.30 & 18.76 & 38.53 & 7 & $\mathrm{~S}$ \\
\hline 42. & ICC-13764 & 70.00 & 56.52 & 63.26 & 9 & HS \\
\hline
\end{tabular}




\begin{tabular}{|c|c|c|c|c|c|c|}
\hline 43. & ICC-16915 & 35.00 & 19.94 & 27.47 & 5 & MS \\
\hline 44. & ICC-283 & 30.00 & 21.85 & 25.92 & 5 & MS \\
\hline 45. & ICC-5434 & 45.00 & 44.26 & 44.63 & 7 & S \\
\hline 46. & ICC-1882 & 75.00 & 30.30 & 52.65 & 9 & HS \\
\hline 47. & ICC-8607 & 56.70 & 42.02 & 49.36 & 7 & $S$ \\
\hline 48. & ICC-8621 & 46.70 & 32.10 & 39.40 & 7 & S \\
\hline 49. & ICC-15567 & 30.00 & 43.68 & 36.84 & 7 & S \\
\hline 50. & ICC-4593 & 30.00 & 22.82 & 26.41 & 5 & MS \\
\hline 51. & ICC-14815 & 13.40 & 30.35 & 21.87 & 5 & MS \\
\hline 52. & ICC-1171 & 36.70 & 34.20 & 35.45 & 7 & $S$ \\
\hline 53. & ICC-1163 & 43.60 & 23.45 & 33.52 & 7 & S \\
\hline 54. & ICC-1883 & 14.30 & 25.95 & 20.62 & 5 & MS \\
\hline 55. & NBeG-168 & 41.70 & 40.44 & 41.07 & 7 & $S$ \\
\hline 56. & NBeG-164 & 41.70 & 27.18 & 34.44 & 7 & S \\
\hline 57. & NBeG-158 & 30.00 & 30.00 & 30.00 & 5 & MS \\
\hline 58. & NBeG-159 & 31.20 & 29.26 & 30.23 & 7 & S \\
\hline 59. & NBeG-170 & 26.70 & 19.80 & 23.25 & 5 & MS \\
\hline 60. & NBeG-169 & 36.70 & 21.24 & 28.97 & 5 & MS \\
\hline 61. & NBeG-161 & 31.81 & 31.81 & 31.81 & 7 & $\mathrm{~S}$ \\
\hline 62. & NBeG-157 & 34.40 & 22.61 & 28.50 & 5 & MS \\
\hline 63. & NBeG-160 & 42.43 & 17.14 & 29.75 & 5 & MS \\
\hline 64. & NBeG-156 & 16.80 & 26.92 & 21.86 & 5 & MS \\
\hline 65. & NBeG-454 & 26.92 & 22.45 & 24.68 & 5 & MS \\
\hline 66. & NBeG-471 & 34.10 & 09.21 & 21.65 & 5 & MS \\
\hline 67. & NBeG-177 & 18.60 & 10.81 & 14.70 & 3 & MR \\
\hline 68. & NBeG-452 & 09.80 & 14.27 & 12.05 & 3 & MR \\
\hline 69. & NBeG-460 & 42.90 & 21.21 & 32.05 & 7 & $\mathrm{~S}$ \\
\hline 70. & NBeG-3 & 08.20 & 10.30 & 09.25 & 1 & $\mathrm{R}$ \\
\hline 71. & NBeG-458 & 15.10 & 06.30 & 10.70 & 3 & MR \\
\hline 72. & NBeG-179 & 27.90 & 15.24 & 21.57 & 5 & MS \\
\hline 73. & NBeG-119 & 08.30 & 11.11 & 09.70 & 1 & $\mathrm{R}$ \\
\hline 74. & NBeG-453 & 31.30 & 05.50 & 24.00 & 5 & MS \\
\hline 75. & NBeG-399 & 28.50 & 30.35 & 29.42 & 5 & MS \\
\hline 76. & NBeG-780 & 24.70 & 20.60 & 22.65 & 5 & MS \\
\hline 77. & NBeG-506 & 33.90 & 17.08 & 25.49 & 5 & MS \\
\hline 78. & NBeG-510 & 31.60 & 12.69 & 22.14 & 5 & MS \\
\hline 79. & NBeG-49 & 04.50 & 06.50 & 05.50 & 1 & $\mathrm{R}$ \\
\hline 80. & NBeG-47 & 10.50 & 09.00 & 09.75 & 1 & $\mathrm{R}$ \\
\hline 81 & NBeG-451 & 21.20 & 20.64 & 20.92 & 5 & MS \\
\hline 82. & NBeG-507 & 37.30 & 17.20 & 27.25 & 5 & MS \\
\hline 83. & JG-11 & 12.00 & 20.00 & 16.00 & 3 & MR \\
\hline 84. & KAK-2 & 28.80 & 45.00 & 36.90 & 7 & $\mathrm{~S}$ \\
\hline \multirow[t]{3}{*}{85.} & NBeG-511 & 21.50 & 29.50 & 25.50 & 5 & MS \\
\hline & JG-62 (S check) & 99.00 & 98.00 & 98.50 & 9 & HS \\
\hline & WR-315 (R check) & 07.60 & 08.00 & 07.80 & 1 & $\mathrm{R}$ \\
\hline
\end{tabular}

R-Resistant, MR-Moderately resistant, MS-Moderately susceptible, S-Susceptible and HS-Highly susceptible 
Table.2 Categorization of chickpea germplasm/genotypes against Fusarium oxysporum f.sp. ciceris at wilt sick plot (Average of two years)

\begin{tabular}{|c|c|c|c|}
\hline $\begin{array}{l}\text { S. } \\
\text { No. }\end{array}$ & Disease reaction & $\begin{array}{l}\text { No. of } \\
\text { entries }\end{array}$ & Entries name \\
\hline 1. & Resistant & 07 & ICC-294, ICC-6279, ICC-14669, NBeG-3, NBeG-49, NBeG-47, NBeG-119 \\
\hline 2. & Moderately resistant & 06 & ICC-67, ICC-1398, NBeG-177, NBeG-452, NBeG-458, JG-11 \\
\hline 3. & Moderately susceptible & 26 & $\begin{array}{l}\text { ICC-1162, ICC-5382, ICC-10945, ICC-1230, ICC-16915, ICC-283, ICC-14815, } \\
\text { ICC-1883, ICC-4593, NBeG-157, NBeG-160, NBeG-158, NBeG-170, NBeG- } \\
\text { 169, NBeG-156, NBeG-454, NBeG-471, NBeG-179, NBeG-453, NBeG-399, } \\
\text { NBeG-506, NBeG-510, NBeG-511, NBeG-451, NBeG-507, NBeG-780 }\end{array}$ \\
\hline 4. & Susceptible & 33 & $\begin{array}{l}\text { ICC-4639, ICC-16524, ICC-5879, ICC-12025, ICC-697, ICC-2942, ICC-3512, } \\
\text { ICC-5383, ICC-3510, ICC-13219, ICC-13863, ICC-9755, ICC-14051, ICC- } \\
\text { 13124, ICC-15618, ICC-5845, ICC-4872, ICC-1923, ICC-14831, ICC-9942, } \\
\text { ICC-9895, ICC-5434, ICC-8607, ICC-8621, ICC-15567, ICC-1171, ICC-1163, } \\
\text { NBeG-168, NBeG-164, NBeG-159, NBeG-161, NBeG-460, KAK-2. }\end{array}$ \\
\hline 5. & Highly susceptible & 13 & $\begin{array}{l}\text { ICC-1397, ICC-14778, ICC-12037, ICC-12328, ICC-6816, ICC-12524, ICC- } \\
\text { 1194, ICC-14402, ICC-867, ICC-2580, ICC-9862, ICC-13764, ICC-1882 }\end{array}$ \\
\hline
\end{tabular}

Table.3 Evaluation of chickpea germplasm/advanced genotypes to

Fusarium wilt in green house conditions

\begin{tabular}{|c|c|c|c|c|c|}
\hline \multirow[t]{3}{*}{ S. No. } & \multirow[t]{3}{*}{ Entry name } & \multicolumn{4}{|c|}{ Wilt incidence (\%) } \\
\hline & & \multirow{2}{*}{$\begin{array}{c}\text { Field } \\
\text { screening }\end{array}$} & \multicolumn{3}{|c|}{ Artificial screening (\%) } \\
\hline & & & Foc-6 & Foc-12 & Foc-17 \\
\hline 1. & NBeG-3 & $\begin{array}{c}09.25 \\
(17.72)\end{array}$ & $\begin{array}{l}00.00 \\
(0.00)\end{array}$ & $\begin{array}{l}00.00 \\
(0.00)\end{array}$ & $\begin{array}{l}00.00 \\
(0.00)\end{array}$ \\
\hline 2. & ICC-1398 & $\begin{array}{c}18.40 \\
(25.41)\end{array}$ & $\begin{array}{c}10.00 \\
(18.44)\end{array}$ & $\begin{array}{c}10.00 \\
(18.44)\end{array}$ & $\begin{array}{c}10.00 \\
(18.44)\end{array}$ \\
\hline 3. & NBeG-119 & $\begin{array}{c}09.70 \\
(18.12)\end{array}$ & $\begin{array}{c}06.66 \\
(14.49)\end{array}$ & $\begin{array}{c}10.00 \\
(18.44)\end{array}$ & $\begin{array}{c}10.00 \\
(18.44)\end{array}$ \\
\hline 4. & ICC-14669 & $\begin{array}{c}05.46 \\
(13.52)\end{array}$ & $\begin{array}{c}00.00 \\
(00.00)\end{array}$ & $\begin{array}{l}00.00 \\
(0.00)\end{array}$ & $\begin{array}{c}00.00 \\
(0.00)\end{array}$ \\
\hline 5. & NBeG-458 & $\begin{array}{c}10.70 \\
(19.10)\end{array}$ & $\begin{array}{c}10.00 \\
(18.44)\end{array}$ & $\begin{array}{c}10.00 \\
(18.44)\end{array}$ & $\begin{array}{c}10.00 \\
(18.44)\end{array}$ \\
\hline 6. & NBeG-49 & $\begin{array}{c}05.50 \\
(13.57)\end{array}$ & $\begin{array}{l}00.00 \\
(0.00)\end{array}$ & $\begin{array}{l}00.00 \\
(0.00)\end{array}$ & $\begin{array}{l}00.00 \\
(0.00)\end{array}$ \\
\hline 7. & NBeG-47 & $\begin{array}{c}09.75 \\
(18.20)\end{array}$ & $\begin{array}{c}03.33 \\
(10.52)\end{array}$ & $\begin{array}{c}03.33 \\
(10.52)\end{array}$ & $\begin{array}{c}10.00 \\
(18.44)\end{array}$ \\
\hline 8. & ICC-6279 & $\begin{array}{c}8.4 \\
(16.86)\end{array}$ & $\begin{array}{l}00.00 \\
(0.00)\end{array}$ & $\begin{array}{l}00.00 \\
(0.00)\end{array}$ & $\begin{array}{l}00.00 \\
(0.00)\end{array}$ \\
\hline 9. & ICC-67 & $\begin{array}{c}11.20 \\
(19.56)\end{array}$ & $\begin{array}{c}10.00 \\
(18.44)\end{array}$ & $\begin{array}{c}10.00 \\
(18.44)\end{array}$ & $\begin{array}{c}10.00 \\
(18.44)\end{array}$ \\
\hline 10. & ICC-294 & $\begin{array}{c}06.90 \\
(15.24)\end{array}$ & $\begin{array}{l}00.00 \\
(0.00)\end{array}$ & $\begin{array}{l}00.00 \\
(0.00)\end{array}$ & $\begin{array}{l}00.00 \\
(0.00)\end{array}$ \\
\hline 11. & NBeG-177 & $\begin{array}{c}14.70 \\
(22.56)\end{array}$ & $\begin{array}{c}20.00 \\
(26.58)\end{array}$ & $\begin{array}{c}19.80 \\
(26.43)\end{array}$ & $\begin{array}{c}18.93 \\
(25.79)\end{array}$ \\
\hline 12. & NBeG-452 & $\begin{array}{c}12.00 \\
(20.28)\end{array}$ & $\begin{array}{c}10.00 \\
(18.44)\end{array}$ & $\begin{array}{c}10.00 \\
(18.44)\end{array}$ & $\begin{array}{c}09.80 \\
(18.23)\end{array}$ \\
\hline \multirow[t]{3}{*}{13.} & JG-11 & $\begin{array}{c}16.00 \\
(23.59)\end{array}$ & $\begin{array}{c}12.50 \\
(20.72)\end{array}$ & $\begin{array}{c}11.50 \\
(20.65)\end{array}$ & $\begin{array}{c}12.50 \\
(20.72)\end{array}$ \\
\hline & JG-62 & $\begin{array}{c}95.00 \\
(77.12)\end{array}$ & $\begin{array}{l}100.00 \\
(90.05)\end{array}$ & $\begin{array}{c}100.00 \\
(90.05)\end{array}$ & $\begin{array}{c}100 \\
(90.05)\end{array}$ \\
\hline & SEm \pm & 2.51 & 0.74 & 0.35 & 0.37 \\
\hline
\end{tabular}

Figures in parenthesis are angular transformed values 
The level of resistance and/or susceptibility for each line was determined by using 1-9 rating scale (Anonymous, 2014)

\begin{tabular}{|c|l|l|}
\hline Scale & PDI & Disease reaction \\
\hline $\mathbf{1}$ & $1-10 \%$ & Resistant \\
\hline $\mathbf{3}$ & $11-20 \%$ & Moderately resistant \\
\hline $\mathbf{5}$ & $21-30 \%$ & Moderately susceptible \\
\hline $\mathbf{7}$ & $31-50 \%$ & Susceptible \\
\hline $\mathbf{9}$ & $51-100 \%$ & Highly susceptible \\
\hline
\end{tabular}

Similar work was carried out by Sharma et al., (2010) who screened twenty five lines each of desi and of kabuli chickpea for Fusarium wilt resistance during 2008-09 in the field (wilt sick plot) and greenhouse at the ICRISAT. Among 25 desi lines screened, 15 lines and 24 lines were found resistant in wilt sick plot and green house respectively. Among 25 kabuli types, seven lines were found resistant in the field and nine lines (including seven resistant lines in the field) showed resistant reaction in the green house.

During 1976 to 1985 , more than 13,500 germplasm accessions available at the ICRISAT gene bank were screened in the wilt sick plot against race 1 of $F$. oxysporum f.sp. ciceris (Haware et al., 1992) and reported 160 accessions resistant to Fusarium wilt through field and greenhouse screening.

When field screening was compared with green house screening, it was found that seven entries such as NBeG-3, NBeG-47, ICC-14669, NBeG-119, NBeG-49, ICC-6279, ICC-294 showed resistant reaction in the field and among them five entries such as NBeG-3, ICC-14669, NBeG-49, ICC-6279 and ICC294 recorded $0 \%$ incidence in green house screening and remaining two entries such as NBeG-47 and NBeG-119 exhibited resistant reaction in the green house screening. Four entries such as ICC-1398, NBeG-458, ICC-67 and NBeG-452 showed moderately resistant reaction in the field and resistant reaction in the green house screening. The entries NBeG-
177 and JG-11 exhibited moderately resistant reaction in both screening methods.

The variation in the resistance/susceptibility of chickpea germplasm and genotypes in the field and polyhouse screening may be due to the prevalence of other soil borne diseases i.e., dry root rot (Rhizoctonia bataticola), collar rot (Sclerotium rolfsii) and wet root rot (Fusarium solani) in wilt sick plot. These are the major diseases of chickpea apart from Fusarium wilt prevalent at RARS, Nandyal. Haware et al., (1992) mentioned that wilt resistant lines often showed some mortality in the field due to the presence of other soil borne pathogens particularly Rhizoctonia bataticola and Sclerotium rolfsii. Sometimes it also might be due to the contamination of one germplasm seed with other germplasm seeds.

Though number of resistance sources identified against wilt across the globe, as mentioned above, continuous change in the genetic makeup of pathogen warrants continuous search for host resistance.

Maitlo et al., (2014) screened 31 cultivars of chickpea against $F$. oxysporum f.sp. ciceris and found no cultivar was completely immune to Foc and cultivars used for screening showed significantly higher plant mortality and pathogen infection. But in the present work there are five germplasm lines/genotypes such as NBeG-3, NBeG-49, ICC-6279 and ICC-294 and ICC-14669 were 
showed complete resistance against $F$. oxysporum f.sp. ciceris.

Among chickpea germplasm/genotypes screened for both natural and artificial methods, the genotypes such as NBeG-3, NBeG-49, NBeG-47, NBeG-119, NBeG-458 and NBeG-452 were recommended for cultivation where Fusarium wilt is the major problem. Germplasm lines such as ICC14669, ICC-6279, ICC-294, ICC-1398 and ICC-67 can be used for Fusarium wilt resistance breeding programme based on their yield potential.

\section{Acknowledgements}

The first author is highly thankful to Dr. V. Jayalakshmi, Principal Scientist (Pl. Breeding) for providing screening material and also to ANGRAU for providing facilities to conduct this experiment.

\section{References}

Anonymous, 2014. AICRP on Chickpea annual work shop. RARI, Durgapura, Rajasthan. $1^{\text {st }}$ August to $3^{\text {rd }}$ September.

Gaur, P.M, Pande, S., Upadhyaya, H.D and Rao, B.V. 2006. Extra large Kabuli chickpea with high resistance to Fusarium wilt. International chickpea and pigeonpea Newsletter. 13: 5-7.

Haware, M.P., Nene, Y.L., Pundir, R.P.S and Narayana Rao, J. 1992. Screening of world chickpea germplasm for resistance to Fusarium wilt. Field Crops Res. 30 (1-2): 147-154.

Hussain, S. K, Ali, S., Ahmad, B., Khan, S.H and Iqbal, M. 2016. Genetic potential of chickpea germplasm against Fusarium wilt (Fusarium oxysporum f.sp. ciceri). Pakistan Journal of Phytopathology. 28 (02): 275-281.

Jalali, B. L. and Chand, H. 1992. Chickpea wilt. Pages 429-444 in: Plant Diseases of International Importance. Vol. I. Diseases of Cereals and Pulses.

Jimenez-Diaz, R.M., Trapero-Casas, A., Colina, J.C.D.L. 1989. Races of Fusarium oxysporum f. sp. ciceris infecting chickpea in southern Spain. In Vascular Wilt Diseases of Plants, Volume H28. Edited by Tjamos EC, Beckman CH. Berlin: NATO ASI Series Springer Verlag. 515-520.

Maitlo, S.A., Rehana, N. Mohammad, S., Khanzada, A., Rajput A.W, Rajput, N.A and Lodhi. A.M. 2014. Host-response of chickpea cultivars to fusarium oxysporum f.sp. ciceris. Pakistan Journal of Phytopathology. 26 (02): 193-199.

Mehmood, Y and Khan, M.A. 2016. Effectiveness of resistant germplasm and biological control agents as a sustainable management for Fusarium wilt disease on chickpea. International Journal of Agricultural Biology. 18: 726-734.

Navas-Cortes, J.A., Hau, B and Jimenez-Diaz, R. M. 2000. Yield loss in chickpea in relation to development to Fusarium wilt epidemics. Phytopathology. 90: 1269-1278.

Nene, Y.L and Haware, M.P. 1980. Screening of chickpea for resistance to wilt. Plant disease. 64 (4).

Nene, Y.L., Sheila, V.K and Sharma, S.B. 1984. A world list of chickpea (Cicer arietinum L.) and Pigeonpea (Cajanus cajan (L) Millsp.) pathogens. ICRISAT Pulse Pathology Progress Report 32: pp.19.

Nene, Y.L., Sheila, V.K., and Sharma, S.B. 1989. A world list of chickpea and pigeon pea Pathogens. In ICRISAT Legume Pathology Program Report, Patancheru, India, p. 7.

Pande, S., Krishna Kishore, G., Upadhyaya, H. D and Rao, J. N., 2006. Identification of sources of multiple disease resistance in mini-core 
collection of chickpea. Plant Disease. 90:1214-1218.

Saabale, P. R., Mishra, R. K., Naimuddin and Chaturvedi, S.K. 2017. New sources of resistance in land races and advance germplasm against Fusarium oxysporum $f$. sp. ciceris race 2 causal agent of chickpea wilt. Legume Research. 40 (2): 364-368.
Sharma, M., Pande, S., Mangala, U.N., Tripathi, S and Gaur, P.M. 2010. Genetic resistance to Desi and Kabuli chickpea lines to Fusarium wilt caused by (Fusarium oxysporum f.sp. ciceris). Indian Journal of Plant Protection. 38 (1): 57-62.

\section{How to cite this article:}

Venkataramanamma, K., B.V. Bhaskara Reddy, R. Sarada Jayalakshmi, V. Jayalakshmi, K.V. Hari Prasad and Mohan Naidu, G. 2018. Screening of Chickpea Germplasm / Genotypes against Fusarium Wilt of Chickpea under Field and Artificial Condition. Int.J.Curr.Microbiol.App.Sci. 7(09): 1041-1050. doi: https://doi.org/10.20546/ijcmas.2018.709.124 